\title{
Influence of diet on the development and regulation of lipogenic enzymes in adipose tissue
}

\author{
BY DOMINIQUE PERDEREAU ${ }^{1}$, FABIENNE FOUFELLE ${ }^{2}$, \\ BETTY GOUHOT ${ }^{1}$, PASCAL FERRE ${ }^{2}$ AND JEAN GIRARD ${ }^{1}$ \\ ${ }^{1}$ Centre de Recherches sur l'Endocrinologie Moléculaire et le Développement, CNRS, 92190 \\ Meudon-Bellevue, France and ${ }^{2}$ Unité 342 INSERM, Hôpital Saint Vincent de Paul, 75014 Paris, \\ France
}

In the rat, the suckling-weaning transition is characterized by a profound change of nutrition. During the suckling period, the pups ingest exclusively milk, which is a high-fat low-carbohydrate diet (Henning, 1981). Toward the end of the second postnatal week of the suckling period, the pups begin to nibble the solid-food diet of the adult rat, which is a high-carbohydrate low-fat diet and weaning is completed after 4 weeks (Redman \& Sweeney, 1976; Henning, 1981). During the first two postnatal weeks, the plasma thyroxine and glucocorticoid concentrations rise (Henning, 1978; Walker et al. 1980) and food intake is not subjected to a circadian rhythm (Walker et al. 1974; Redman \& Sweeney, 1976; Henning et al. 1979). The typical rhythm of food intake of adult rats begins after 4 weeks (most food consumption occurring during darkness). The nutritional changes at weaning are accompanied by an increase in plasma insulin and a decrease in plasma glucagon concentrations (Girard et al. 1977).

At birth, the rat is devoid of white adipose tissue and the size of fat pads remains very small during the suckling period. However, following weaning, a considerable increase in the size of white adipose tissue occurs (Hahn \& Novak, 1975; Cryer, 1982; Greenwood \& Hirsch, 1984). The accumulation of fat in white adipose tissue results from two processes: (1) the uptake of circulating triacylglycerol under the action of lipoprotein lipase (EC 3.1.1.34) and (2) the de novo synthesis of fatty acids from glucose (lipogenesis). It has been reported that lipoprotein lipase activity is low at birth, increases during the first ten postnatal days (during the active phase of adipocyte proliferation) and decreases to extremely low values before increasing after weaning (Cryer, 1982). However, as lipoprotein lipase is an early marker of adipocyte differentiation, the metabolic significance of these changes is not obvious. The absence of fat accumulation in white adipose tissue despite the high level of circulating triacylglycerol during the suckling period suggests that lipoprotein lipase is not in an active form. The migration of lipoprotein lipase from the adipose cells to the vascular epithelium, where this enzyme hydrolyses circulating triacylglycerol, has been shown to be controlled by insulin. The low concentration of plasma insulin during the suckling period could limit adipose tissue lipoprotein lipase activity and the marked increases of plasma insulin after weaning could play an important role in activation of lipoprotein lipase (Cryer, 1982). The rates of glucose utilization in vivo and of lipogenesis are very low in white adipose tissue during the suckling period and markedly increase after weaning onto a highcarbohydrate (HC) diet (Hahn, 1970; Tsujikawa \& Kimura, 1980; Gandemer et al. 1982; Issad et al. 1988). Basal and insulin-stimulated glucose metabolism are also very low in isolated adipocytes during the suckling period but increase markedly after weaning onto a high-fat (HF) diet (Tsujikawa \& Kimura, 1980; Issad et al. 1989). In contrast, weaning 
onto an HF diet entirely prevents the increase in the rate of glucose utilization in vivo, in the rate of lipogenesis and the increase in sensitivity to insulin of white adipose tissue (Tsujikawa \& Kimura, 1980; Issad et al. 1988, 1989). The aim of the present paper is to review the nutritional and hormonal factors involved in the regulation of lipogenic enzyme gene expression in adipose tissue during the suckling-weaning transition.

\section{CHANGES IN LIPOGENIC ENZYME ACTIVITIES IN ADIPOSE TISSUE DURING THE SUCKLING-WEANING TRANSITION}

The activities of three major lipogenic enzymes: fatty acid synthase ( $E C 2.3 .1 .85$; FAS), acetyl-CoA carboxylase ( $E C$ 6.4.1.2; ACC) and ATP-citrate lyase ( $E C$ 4.1.3.8; ATP-CL) and of phosphoenolpyruvate carboxykinase (EC 4.1.1.32; PEPCK) were studied. PEPCK is an enzyme involved in glyceroneogenesis, a pathway similar to the first part of gluconeogenesis. This enzyme is involved in the generation of glycerol-3phosphate in adipose tissue and is important for the maintenance of fatty acid esterification in situations of glucose shortage (Ballard et al. 1967; Reshef et al. 1970). In the adipose tissue of adult rats, starvation increases the activity and synthesis of PEPCK, whereas refeeding has the opposite effects (Hopgood et al. 1973). It was chosen as a negative marker of lipogenic enzyme gene expression.

FAS, ACC and ATP-CL activities are very low in white adipose tissue of 15-d-old suckling rats but increase twentyfold after weaning onto an $\mathrm{HC}$ diet (Tsujikawa \& Kimura, 1980; Coupé et al. 1990). In contrast, the activity of PEPCK was threefold lower in HC-weaned rats than in the suckling rats (Coupé et al. 1990). In an attempt to determine whether the nutrition or the stage of development was involved in the changes observed, the activities of lipogenic enzyme were measured in 30-35-d-old rats weaned onto an HF diet. Weaning onto an HF diet prevents the increase of FAS, ACC, ATP-CL and the decrease of PEPCK activities observed when suckling rats are weaned onto an HC diet (Fig. 1; Tsujikawa \& Kimura, 1980; Coupé et al. 1990). This clearly shows that the nutritional changes are important for the normal development of lipogenic capacity in adipose tissue.

\section{CHANGES IN LIPOGENIC ENZYME MRNA CONCENTRATIONS IN ADIPOSE TISSUE DURING THE SUCKLING-WEANING TRANSITION}

There is very little information available concerning the precise time-course of changes of lipogenic enzyme activities in adipose tissue, their dietary and hormonal regulations or the molecular mechanisms involved (transcriptional or post-transcriptional regulation). The recent availability of specific cDNA probes for FAS (Nepokroeff et al. 1984; Yan et al. 1985), ATP-CL (Elshourbagy et al. 1990), ACC (Bai et al. 1986) and PEPCK (Yoo-Warren et al. 1981) has prompted us to study the role of hormones and of nutrients in the changes of the expression of these genes in adipose tissue at weaning in the rat. In adult rats, changes in the activities of these enzymes are related to variations in their rate of synthesis (Nakanishi \& Numa, 1970; Volpe \& Marasa, 1975). Thus, the increased enzyme activities at weaning are probably linked to an increased protein mass.

In an attempt to investigate early events involved in the synthesis of these enzymes, we have measured the concentrations of their specific mRNA. In suckling and HC-weaned 
Fatty acid synthetase

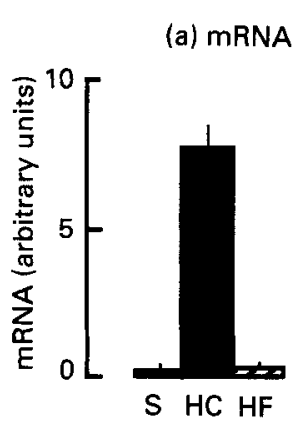

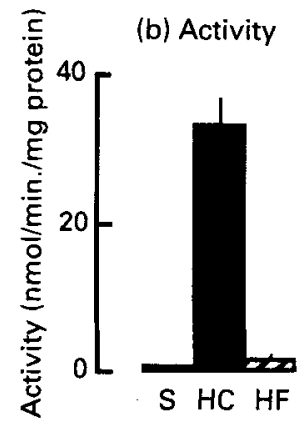

Acetyl-CoA carboxylase

(a) mRNA

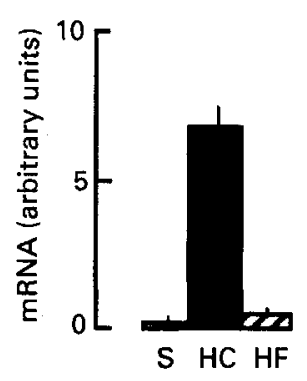

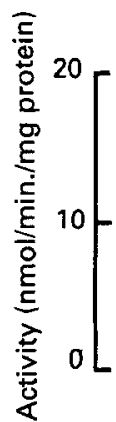

(b) Activity

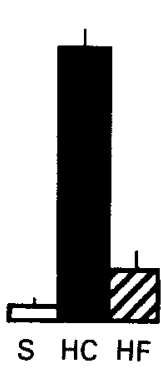

\section{ATP-citrate lyase}

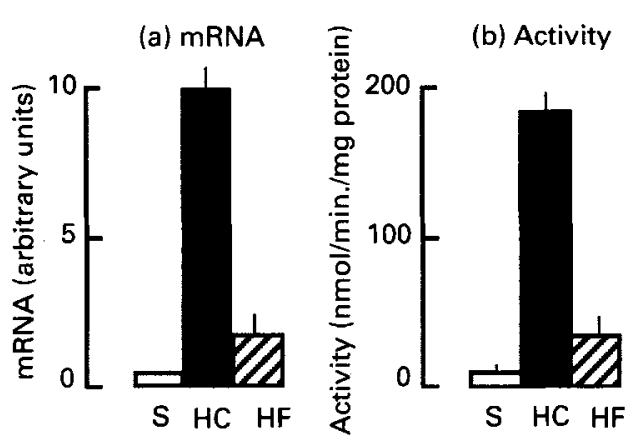

Fig. 1. Fatty acid synthase ( $E C$ 2.3.1.85), acetyl-CoA carboxylase ( $E C$ 6.4.1.2) and ATP-citrate lyase (EC 4.1.3.8) $\mathrm{mRNA}$ and activities after weaning onto a high-carbohydrate (HC) or a high-fat (HF) diet. The suckling rats (S) were 15 -d old and the weaned rats were 30 or 35 -d old and had been weaned onto an $\mathrm{HC}$ or $\mathrm{HF}$ diet at 21 or $25 \mathrm{~d}$. Values are the means with their standard errors, represented by vertical bars, of four to seven determinations. Redrawn from Coupé et al. (1990) and Tsujikawa \& Kimura (1980).

rats, the mRNA concentrations vary in parallel with the changes of enzyme activities (Coupé et al. 1990). FAS and ACC mRNA are barely detectable in the adipose tissue of suckling rats, but are markedly increased after weaning onto $\mathrm{HC}$, whereas PEPCK mRNA presents a totally inverse variation (Coupé et al. 1990). Similar findings have been obtained for ATP-CL mRNA (D. Perdereau and J. Girard, unpublished results). The FAS, ACC and ATP-CL relative mRNA concentrations are respectively six- to seventeenfold higher in $\mathrm{HC}$-weaned rats than in suckling rats. Conversely, PEPCK mRNA concentration is sixteenfold lower after weaning onto the $\mathrm{HC}$ diet. Weaning onto an HF diet prevented the changes of FAS, ACC, ATP-CL and PEPCK mRNA concentrations observed when suckling rats were weaned onto an $\mathrm{HC}$ diet (Coupé et al. 1990). 


\section{TIME-COURSE OF CHANGES IN MRNA CONCENTRATIONS DURING THE SUCKLING-WEANING TRANSITION}

In order to determine the kinetics of the increase of FAS, ACC and ATP-CL mRNA, and the disappearance of PEPCK mRNA that occur at weaning onto the $\mathrm{HC}$ diet, suckling rats were artificially weaned. To avoid any starvation period that occurs during a premature (15 d) artificial weaning, the suckling rats were kept with their mother until 21 $\mathrm{d}$ of age, and then abruptly weaned onto an HC diet. Since suckling rats begin to nibble the mother's food from $15 \mathrm{~d}$ of age, the mothers were fed on an HF diet, having verified that nibbling a solid carbohydrate-free diet by the pups did not modify the studied variables. The FAS, ACC, ATP-CL and PEPCK mRNA concentrations do not increase between 15 and $21 \mathrm{~d}$. FAS, ACC, ATP-CL mRNA concentrations on one hand, and PEPCK mRNA concentration on the other hand, show totally opposite time-course (Coupé et al. 1990; D. Perdereau and J. Girard, unpublished results). FAS, ACC and ATP-CL mRNA concentrations are barely detectable before weaning and reach 68,21 and $94 \%$ of the maximal value respectively in the first $24 \mathrm{~h}$. Corresponding values are 90 , 81 and $100 \%$ after $48 \mathrm{~h}$ and are maximal $96 \mathrm{~h}$ after the weaning for all enzymes. In contrast, PEPCK mRNA concentration falls to its lowest value in the first $24 \mathrm{~h}$ and remains very low thereafter (Coupé et al. 1990). Weaning onto an HC diet results in a threefold increase in plasma insulin concentration after $24 \mathrm{~h}$ and the plasma insulin concentration remains elevated until the rat is $25 \mathrm{~d}$ old. Enzyme activities follow a similar pattern to that of mRNA but with a lag period of about $24 \mathrm{~h}$, suggesting that transcriptional regulation plays an important role in activity levels.

\section{CARBOHYDRATE FEEDING IN 21-D-OLD SUCKLING RATS}

To further assess the role of carbohydrates in the large variations in FAS, ACC, ATP-CL and PEPCK mRNA concentrations occurring at weaning onto an HC diet, 21-d-old suckling rats were force-fed with a mixture of sucrose and starch (Coupé et al. 1990). Blood glucose and plasma insulin concentrations rapidly increase in carbohydrate-fed rats to reach maximal values after $1 \mathrm{~h}$ and remain elevated during the following $5 \mathrm{~h}$. At 4-6 h after carbohydrate feeding FAS and ACC mRNA concentrations increase by respectively six- to eighteenfold and PEPCK mRNA concentration falls to $20 \%$ of the suckling values. FAS, ACC and PEPCK mRNA do not change significantly when 21-d-old suckling rats are force-fed with the lipid portion of the HF diet.

These findings suggest that a direct relationship exists between plasma insulin, blood glucose and the rise in lipogenic enzyme mRNA concentrations. This is in keeping with a recent study showing that the low concentration of ACC mRNA in the adipose tissue of streptozotocin-diabetic rats, is restored to normal levels $6 \mathrm{~h}$ after insulin injection (Pape et al. 1988). Thyroid hormones have been shown to stimulate the expression of lipogenic enzyme mRNA (Goodridge, 1987; Katsurada et al. 1990a,b). In the present study, it is unlikely that thyroid hormones played a role in the changes of FAS and ACC mRNA concentrations. Indeed, plasma triiodothyronine concentration was not increased in rats weaned onto HC or HF diets compared with 15-d-old suckling rats (Coupé et al. 1990). However, it must be pointed out that the plasma concentrations of thyroid hormones had reached the adult level just before weaning (Walker et al. 1980; Henning, 1981) and, thus, could play a permissive role in the induction of lipogenic enzymes in response to carbohydrate and insulin. 


\section{CHANGES IN LIPOGENIC ENZYME MRNA CONCENTRATIONS IN ADIPOSE TISSUE AFTER WEANING ONTO A BALANCED DIET CONTAINING LONG-CHAIN (LCT) OR MEDIUM-CHAIN TRIACYLGLYCEROLS (MCT)}

A number of studies have suggested that diets rich in fat, and particularly diets rich in polyunsaturated fatty acids, decrease the lipogenic capacity of adipose tissue of adult rat (Romsos \& Leveille, 1974; Clarke et al. 1977; Toussant et al. 1981). More recently, it has been shown that diets rich in polyunsaturated fatty acids decrease FAS and ACC mRNA abundance in liver and adipose tissue of adult rats (Clarke et al. 1990; Katsurada et al. $1990 a, b$; Shillabeer et al. 1990). Diets containing MCT have been found to have divergent effects on the lipogenic capacity and lipogenic enzyme activities of adipose tissue and liver of adult rats, depending on the amount of MCT in the diet. MCT-rich diets (60\% of the energy) have been reported to decrease (Lavau \& Hashim, 1978) or to increase (Takase \& Hosoya, 1986) the activity of lipogenic enzymes. Diets containing moderate amounts of MCT (30\% of the energy) did not affect the activity of lipogenic enzymes (Chanez et al. 1991). In order to investigate the effect of the nature of fatty acids in the diet on the changes of FAS and ACC activities and mRNA concentrations occurring at weaning, suckling rats were abruptly weaned at $21 \mathrm{~d}$ onto a carbohydraterich diet ( $50 \%$ of total energy) containing either LCT or MCT ( $30 \%$ of energy). Suckling rats weaned onto an $\mathrm{HC}$ diet were used as controls, since it was previously shown that it induces a maximal increase of FAS and ACC mRNA concentrations and activities (Coupé et al. 1990).

Weaning onto the MCT diet does not prevent the increase in FAS and ACC mRNA and activities that occur normally in adipose tissue after weaning onto an $\mathrm{HC}$ diet (Foufelle et al. 1992b, Fig. 2). However, the mRNA accumulation was slightly delayed when compared with that observed in $\mathrm{HC}$-weaned rats. In contrast, the accumulation of FAS and ACC mRNA was less in rats weaned onto the LCT diet when compared with the rats weaned onto the MCT diet. FAS and ACC activities followed a pattern similar to that described for mRNA but the changes were less marked suggesting a post-transcriptional control of enzyme concentration in addition to a translational regulation. Since the carbohydrate content is similar in MCT and LCT diets, it is likely that the lower lipogenic enzyme mRNA and activities after weaning onto the LCT diet were specific for the long-chain fatty acids and not a consequence of a lower carbohydrate consumption. The inability of MCT to inhibit lipogenic enzyme gene expression in adipose tissue after weaning could be simply due to their particular metabolic fate. Medium-chain fatty acids arising from intestinal triacylglycerol hydrolysis are not re-esterified in the intestine and enter the plasma compartment through the portal vein. They are extensively removed from the portal blood by the liver and, thus, adipose tissue is never exposed to high concentrations of medium-chain fatty acids. Another possible explanation of the different effects of MCT and LCT on lipogenic enzyme gene expression relates to the concentration of plasma insulin. Insulin is probably involved in the increased lipogenic enzyme gene expression in adult and weaned rats (Pape et al. 1988; Paulauskis \& Sul, 1989; Coupé et al. 1990; Perdereau et al. 1990). In the present study, plasma insulin concentrations were significantly lower in LCT-weaned rats $(30 \mu \mathrm{U} / \mathrm{ml})$ than in MCT-weaned rats $(60 \mu \mathrm{U} / \mathrm{ml})$. This is due to the fact that MCT consumption induces much higher plasma ketone body concentrations than LCT (Yeh \& Zee, 1976) and that high plasma levels of ketone bodies stimulate insulin release in the rat (Hawkins et al. 1971). Thus, the lower plasma insulin observed in the LCT-weaned rats could be one of 
Fatty acid synthase

(a) mRNA

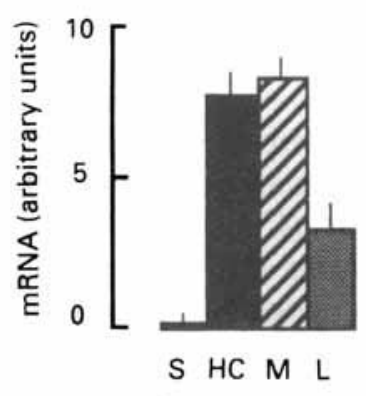

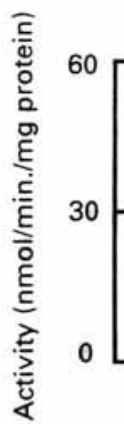

(b) Activity

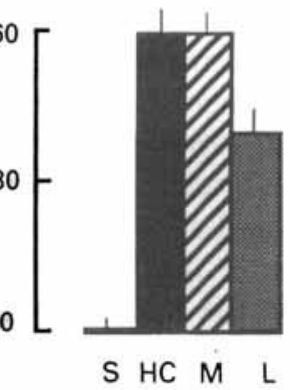

Acetyl-CoA carboxylase

(a) mRNA

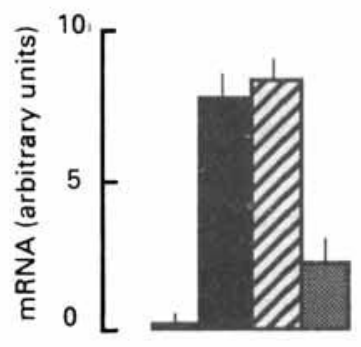

$S$ HC M L

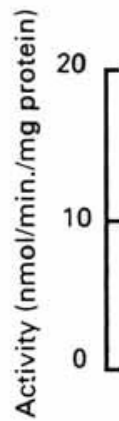

(b) Activity

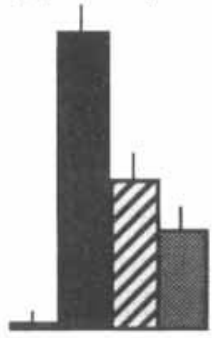

$S \mathrm{HC} \mathrm{M} \mathrm{L}$

Fig. 2. Fatty acid synthase (EC 2.3.1.85) and acetyl-CoA carboxylase (EC 6.4.1.2) mRNA and activities after weaning onto a high-carbohydrate (HC) or balanced diets containing medium-chain (M) or long-chain (L) triacylglycerols. The suckling rats (S) were $15-\mathrm{d}$ old and the weaned rats were $30-\mathrm{d}$ old and had been weaned onto an $\mathrm{HC}$ or balanced diets containing $\mathrm{M}$ or $\mathrm{L}$ triacylglycerols at $21 \mathrm{~d}$. Values are the means with their standard errors, represented by vertical bars, for four to seven determinations. Redrawn from Foufelle et al. (1992a).

the factors contributing to the inhibitory effect of LCT on lipogenic enzyme expression after weaning in comparison with MCT.

\section{CHANGES IN LIPOGENIC ENZYME MRNA CONCENTRATIONS IN CULTURED ADIPOSE TISSUE EXPLANTS FROM SUCKLING RATS}

Explants from adipose tissue of 19-d-old suckling rats were cultured 6-24 $\mathrm{h}$ in a serum-free minimal essential medium (Foufelle et al. 1992a). A large accumulation of FAS and ACC mRNA was observed in explants of adipose tissue cultured in the presence of insulin $\left(10^{-7} \mathrm{M}\right)$ and glucose $(5 \mathrm{mM})$. Insulin did not induce FAS and ACC mRNA accumulation when the culture medium was deprived of glucose, but the effects of insulin on FAS and ACC mRNA levels were markedly potentiated when the glucose concentration in the medium was increased to 10 and $20 \mathrm{~mm}$ (Foufelle et al. 1992a). The 
effects of glucose and insulin on FAS and ACC mRNA levels were antagonized by dexamethazone, glucagon and isoproterenol and were potentiated by thyroid hormones. Thus, insulin and glucose are the main factors involved in the initial induction of FAS and ACC mRNA in white adipose tissue.

\section{CONCLUSION}

The series of experiments carried out both in vivo and in vitro strongly support the view that the marked increase in lipogenic enzyme mRNA concentrations and activities that occur in white adipose tissue after weaning onto an HC-diet is dependent on an increase in plasma insulin concentration. An increased glucose metabolism in white adipose tissue is necessary to the expression of insulin effects on FAS and ACC mRNA accumulation since insulin is ineffective in vitro in the absence of glucose. It has been suggested recently that glucose-6-phosphate could play an important role in the effect of insulin on lipogenic enzyme gene expression in white adipose tissue (Foufelle et al. 1992a). Other hormones and substrates could also play a role in the surge of lipogenesis after weaning. The fall in plasma glucagon after weaning onto an $\mathrm{HC}$ diet could reinforce the insulin-induced accumulation of FAS and ACC mRNA since this hormone inhibits lipogenic enzyme expression in white adipose tissue. The decrease in the dietary supply of fat and the fall in plasma free fatty acids after weaning onto an $\mathrm{HC}$ diet could also potentiate the accumulation of FAS and ACC mRNA since long-chain fatty acids and particularly polyunsaturated fatty acids are potent inhibitors of lipogenic enzyme gene expression.

The authors thank Drs. A. G. Goodridge, R. W. Hanson, and K. H. Kim for kindly providing us with the cDNA probes used in these studies and Dr. N. Katz, Universität of Giessen, Germany, for providing the oligonucleotide ( $42 \mathrm{mer}$ ) cDNA probe encoding the sequence +1518 to +1559 of ATP-CL. They also thank D. Chamereau for taking care of the animals.

This work was supported in part by grants from the Ministère de la Recherche et de la Technologie ( ${ }^{\circ} 88-\mathrm{G}-0119$ and $\left.90-\mathrm{G}-0292\right)$ and by a grant from Fondation pour la Recherche Médicale, France.

\section{REFERENCES}

Bai, D. H., Pape, M. E., Lopez-Casillas, F., Luo, X. C., Dixon, J. E. \& Kim, K. H. (1986). Molecular cloning of cDNA for acetyl-CoA carboxylase. Journal of Biological Chemistry 261, 12395-12399.

Ballard, F. J., Hanson, R. W. \& Leveille, G. A. (1967). Phosphoenolpyruvate carboxykinase and the synthesis of glyceride-glycerol from pyruvate in adipose tissue. Journal of Biological Chemistry 242, 2746-2750.

Chanez, M., Bois-Joyeux, B., Arnaud, M. J. \& Peret, J. (1991). Metabolic effects in rats of a diet with a moderate level of medium-chain triglycerides. Journal of Nutrition 121, 585-594.

Clarke, S. D., Armstrong, M. K. \& Jump, D. B. (1990). Dietary polyunsaturated fats uniquely suppress rat liver fatty acid synthase and S14 messenger RNA content. Journal of Nutrition 120, 225-231.

Clarke, S. D., Romsos, D. R. \& Leveille, G. A. (1977). Differential effects of dietary methyl esters of long-chain saturated and polyunsaturated fatty acids on rat liver and adipose tissue lipogenesis. Journal of Nutrition 107, 1170-1181.

Coupé, C., Perdereau, D., Ferré, P., Hitier, Y., Narkewicz, M. \& Girard. J. (1990). Lipogenic enzyme activities and mRNA in rat adipose tissue during weaning: role of the diet. American Journal of Physiology 258, E126-E133. 
Cryer, A. (1982). The growth and metabolism of developing white adipose tissue. In The Biochemical Development of the Fetus and Neonate, pp. 731-758 [C. T. Jones, editor]. Amsterdam: Elsevier.

Elshourbagy, N. A., Near, J. C., Kmetz, P. J., Sathe, G. M., Southan, C., Strickler, J. E., Gross, M., Young, J. F., Wells, T. N. C. \& Groot, P. H. E. (1990). Rat ATP citrate-lyase. Molecular cloning and sequence analysis of a full-length cDNA and messenger RNA abundance as a function of diet, organ, and age. Journal of Biological Chemistry 265, 1430-1435.

Foufelle, F., Gouhot, B., Pegorier, J-P., Perdereau, D., Girard, J. \& Ferré, P. (1992a). Glucose stimulation of lipogenic enzyme gene expression in cultured white adipose tissue: a role for glucose-6-phosphate. Journal of Biological Chemistry 267 (In the Press).

Foufelle, F., Perdereau, D., Gouhot, B., Ferré, P. \& Girard, J. (1992b). Effects of diets rich in medium and long chain triglycerides on lipogenic enzyme gene expression in liver and adipose tissue of the weaned rat. European Journal of Biochemistry 208, 381-387.

Gandemer, G., Pascal, G. \& Durand, G. (1982). In vivo changes in the rates of total lipid and fatty acid synthesis in liver and white adipose tissues of male rats during post-weaning growth. International Journal of Biochemistry 14, 797-804.

Girard, J. R., Ferré, P., Kervran, A., Pégorier, J. P. \& Assan, R. (1977). In Glucagon: Its Role in Physiology and Clinical Medicine, pp. 563-581 [P. P. Foa, J. S. Bajaj and N. L. Foa, editors]. New York: Springer-Verlag.

Greenwood, M. R. C. \& Hirsch, J. (1984). Postnatal development of adipocyte cellularity in the normal rat. Journal of Lipid Research 15, 474-483.

Goodridge, A. G. (1987). Dietary regulation of gene expression: enzymes involved in carbohydrate and lipid metabolism. Annual Review of Nutrition 7, 157-185.

Hahn, P. (1970). Fatty-acid synthesis in brown and white adipose tissue and liver of the rat during development. Physiological Bohemoslovaka 19, 369-373.

Hahn, P. \& Novak, M. (1975). Development of brown and white adipose tissue. Journal of Lipid Research 16, 79-91.

Hawkins, R. A., Alberti, K. G. M. M., Houghton, C. R. S., Williamson, D. H. \& Krebs, H. A. (1971). The effect of acetoacetate on plasma insulin concentration. Biochemical Journal 125, 541-544.

Henning, S. J. (1978). Plasma concentration of total and free corticosterone during development in the rat. American Journal of Physiology 235, E451-E456.

Henning, S. J. (1981). Postnatal development: coordination of feeding, digestion, and metabolism. American Journal of Physiology 241, G199-G214.

Henning, S. J., Chang, S. S. P. \& Gisel, E. G. (1979). Ontogeny of feeding controls in suckling and weanling rats. American Journal of Physiology 237, R187-R191.

Hopgood, M. F., Ballard, F. J., Reshef, L. \& Hanson, R. W. (1973). Synthesis and degradation of phosphoenolpyruvate carboxykinase in rat liver and adipose tissue. Changes during a starvation-refeeding cycle. Biochemical Journal 134, 445-453.

Issad, T., Coupé, C., Pastor-Anglada, M., Ferré, P. \& Girard, J. (1988). Development of insulin-sensitivity at weaning in the rat. Role of the nutritional transition. Biochemical Journal 251, 685-690.

Issad, T., Ferré, P., Pastor-Anglada, M., Baudon, M. A. \& Girard, J. (1989). Development of insulin sensitivity in white adipose tissue during the suckling-weaning transition in the rat: involvement of glucose transport and lipogenesis. Biochemical Journal 264, 217-222.

Katsurada, A., Iritani, N., Fukuda, H., Matsumura, Y., Nishimoto, N., Noguchi, T. \& Tanaka, T. (1990a). Effects of nutrients and hormones on transcriptional and post transcriptional regulation of fatty acid synthase in rat liver. European Journal of Biochemistry 190, 427-433.

Katsurada, A., Iritani, N., Fukuda, H., Matsumura, Y., Nishimoto, N., Noguchi, T. \& Tanaka, T. (1990b). Effects of nutrients and hormones on transcriptional and post transcriptional regulation of acetyl-CoA carboxylase in rat liver. European Journal of Biochemistry 190, 435-441.

Lavau, M. \& Hashim, S. A. (1978). Effects of medium chain triglycerides on lipogenesis and body fat in the rat. Journal of Nutrition 108, 613-620.

Nakanishi, S. \& Numa, A. (1970). Purification of rat liver acetyl coenzyme A carboxylase and immunochemical studies on its synthesis and degradation. European Journal of Biochemistry 16, 161-173.

Nepokroeff, C. M., Adachi, K., Yan, C. \& Porter, J. W. (1984). Cloning of DNA complementary to rat liver fatty acid synthetase mRNA. European Journal of Biochemistry 140, 441-445.

Pape, M. E., Lopez-Casillas, F. \& Kim, K. H. (1988). Physiological regulation of acetyl-CoA carboxylase gene expression: effects of diet, diabetes and lactation on acetyl-CoA carboxylase mRNA. Archives of Biochemistry and Biophysics 267, 104-109. 
Paulauskis, J. D. \& Sul, H. K. (1989). Hormonal regulation of mouse fatty acid synthase gene transcription in liver. Journal of Biological Chemistry 264, 574-577.

Perdereau, D., Narkewicz, M., Coupé, C., Ferré, P. \& Girard, J. (1990). Hormonal control of specific gene expression in the rat during the suckling-weaning transition. Advances in Enzyme Regulation 30, 91-107.

Redman, R. S. \& Sweeney, L. R. (1976). Changes in diet and patterns of feeding activity of developing rats. Journal of Nutrition 106, 615-626.

Reshef, L., Hanson, R. W. \& Ballard, J. F. (1970). A possible physiological role for glycerolneogenesis in rat adipose tissue. Journal of Biological Chemistry 245, 5979-5984.

Romsos, D. R. \& Leveille, G. A. (1974). Effect of diet on activity of enzymes involved in fatty acid and cholesterol synthesis. Advances in Lipid Research 12, 97-146.

Shillabeer, G., Hornford, J., Forden, J. M., Wong, N. C. W. \& Lau, D. C. W. (1990). Hepatic and adipose tissue lipogenic enzyme mRNA are suppressed by high fat diets in the rat. Journal of Lipid Research 31, 623-631.

Takase, S. \& Hosoya, N. (1986). Effect of dietary medium chain triglyceride on lipogenic enzyme activity in rat liver. Journal of Nutritional Science and Vitaminology 32, 219-227.

Toussant, M. J., Wilson, M. D. \& Clarke, S. D. (1981). Coordinate suppression of liver acetyl-CoA carboxylase and fatty acid synthetase by polyunsaturated fat. Journal of Nutrition 111, 146-153.

Tsujikawa, M. \& Kimura, S. (1980). Changes in lipid synthesis in rat adipose tissue during development. Journal of Nutritional Science and Vitaminology 26, 367-374.

Volpe, J. J. \& Marasa, J. C. (1975). Hormonal regulation of fatty acid synthetase, acetyl-CoA carboxylase and fatty acid synthesis in mammalian adipose tissue and liver. Biochimica et Biophysica Acta 380, 454-472.

Walker, P., Dubois, J. D. \& Dussault, J. H. (1980). Free thyroid hormone concentrations during the postnatal development in the rat. Pediatric Research 14, 247-249.

Walker, P. R., Bonney, R. J. \& Van Potter, R. (1974). Diurnal rhythms of hepatic carbohydrate metabolism during development of the rat. Biochemical Journal 140, 523-529.

Yan, C., Wood, E. A. \& Porter, J. W. (1985). Characterization of fatty acid synthetase cDNA clone and its mRNA. Biochemical and Biophysical Research Communications 126, 1235-1241.

Yeh, Y. Y. \& Zee, P. (1976). Relation of ketosis to metabolic changes induced by acute medium chain triglyceride feeding in rats. Journal of Nutrition 106, 58-67.

Yoo-Warren, H., Cimbala, M. A., Felz, K., Monahan, J. E., Leis, J. P. \& Hanson, R. W. (1981) Identification of a cDNA clone to phosphoenolpyruvate carboxykinase (GTP) from rat cytosol. Alterations in RNA levels detectable by hybridization. Journal of Biological Chemistry 256, 10224-10227. 